\title{
PENGGUNAAN STRATEGI INKUIRI DALAM PEMBELAJARAN ISOLASI BAKTERI ASAL MOL DAN PENERAPANNYA SEBAGAI PUPUK HAYATI
}

\author{
Meli Astriani ${ }^{1)}$, Ervina Mukharomah ${ }^{2}$ \\ 1)2) Program Studi Pendidikan Biologi, FKIP Universitas Muhammadiyah Palembang \\ Jl. Jendral Ahmad Yani, 13 Ulu, Kota Palembang, Sumatera Selatan 30252, Indonesia \\ e-mail: meliastriani.g021@gmail.com
}

Diterima 17 Februari 2017, dan disetujui 30 Maret 2017

\begin{abstract}
This study aims to utilize household waste and used MOL (Micro-Organism-Local). MOL is used to assist the process of decomposition in composting. This study aims to isolate the bacterial origin of MOL with media of different organic materials and the application of the isolated bacteria as a biological fertilizer. Stages of research involved isolating bacteria from MOL vegetables, then do purification. The next stage is to identify the bacteria colony morphology that includes forms, cells, and Gram. This research is expected to contribute to the field, namely: the development of science, research methodology. First, for science to improve information research methods, research for further development activities for people who have an interest in the processing of biological fertilizers and organic fertilizers. Second, the methodology how to obtain microbes for use in applied research. The results were obtained bacterial isolates were collected from three kinds of treatment samples MOL namely MOL to-I (waste vegetable, sugar, rice water), II (vegetable waste, brown sugar, rice water), and III (waste vegetable, sugar sand, coconut water). The result of the isolation and purification of bacteria obtained amounted to 79 types of bacterial isolates comprising 23 species of bacteria from the sample MOL to-1, 30 species of bacteria from the sample to the MOL-II, and 24 types of bacteria from the sample to-III. Overall the data obtained from the sample to the MOL-I, II, and III of the highest number of bacterial cells present in the sample to the MOL-II with a number of types of bacteria most. This type of bacteria that is known at the time $\mathrm{T} 0, \mathrm{~T} 1$.
\end{abstract}

Keywords: Isolation, Biofertilizer, MOL

\section{PENDAHULUAN}

Pengolahan sampah saat ini masih menjadi hal yang meresahkan. Oleh sebab itu dicari solusi untuk memecahkan masalah sampah sehingga ramah lingkungan, selain itu di lain pihak menjadi pertimbangan lain pada penggunaan pupuk anorganik pada tanaman masih menjadi pilihan di kalangan petani. Penggunaan pupuk anorganik dalam jangka waktu yang panjang akan mempengaruhi tingkat kesuburan tanah. Banyak masyarakat memanfaatkan teknik pembuatan MOL untuk membantu mempercepat proses pembuatan kompos. Menurut NOSC (2008) bahwa MOL (mikroorganisme lokal) merupakan cairan atau starter dalam pembuatan kompos dan dibuat menggunakan bahan yang ada di sekitar kita seperti limbah sayuran, rebung, limbah buah-buahan, dan nasi.

Keunggulan penggunaan MOL yaitu bahan yang digunakan mudah dan murah untuk dibuat. Dalam pembuatan MOL dibutuhkan beberapa campuran yang mengandung glukosa, air kelapa untuk membantu proses fermentasi yang berlangsung. Cairan MOL yang telah dibuat dapat digunakan sebagai aktivator proses pembuatan kompos yang berasal dari sampah organik (NOSC, 2008). MOL hasil pembuatan masyarakat dianggap kurang optimal untuk memberikan pengaruh pada kompos. Waktu pengomposan yang dibutuhkan cukup lama dan harus diperkaya dengan agen biologi yang komersial. 
Salah satu cara mendapatkan agen biologi komersial yaitu dengan mencari potensi dari bakteri yang mempunyai fungsi sebagai biofertilizer. Komposisi mikroba dekomposer yang diperkaya dapat membantu proses penghancuran sampah organik dalam waktu beberapa minggu bahkan beberapa hari saja. Suhastyo (2011) melaporkan berbagai macam mikroorganisme yang terlibat dalam proses penghancuran sampah antara lain Azotobacter dan Azospirillum.

Berdasarkan penelitian Batara (2015) pengaruh MOL yang diperkaya dalam meningkatkan pertumbuhan dan produksi tanaman padi memberi pengaruh yang tinggi terhadap pertumbuhan vegetatif tanaman dibandingkan tanpa pemberian MOL. MOL yang berasal dari rebung bambu yang diperkaya mikroorganisme mempunyai kemampuan $61 \%$ terhadap pertumbuhan tanaman.

Cairan MOL mengandung Mikroorganisme yang menguntungkan karena sampai saat ini masih digunakan masyarakat sebagai media yang membantu dalam pembuatan kompos. Cairan dalam MOL mengandung bakteri yang dapat membantu proses penghancuran bahan organik untuk membuat kompos. Kompos yang mengandung bakteri diketahui dapat memacu pertumbuhan tanaman dan menyediakan nutrisi bagi tanaman. sehingga berdasarkan keterangan tersebut maka perlu dilakukan penelitian isolasi bakteri dari MOL dan penerapannya sebagai agen biologis untuk dibuat pupuk hayati.

Penelitian ini diharapkan dapat berkontribusi pada kemajuan ilmu pengetahuan, yakni: bidang pengembangan ilmu, bidang metodologi penelitian. Pertama, bagi ilmu pengetahuan dengan meningkatkan informasi metode penelitian, hasil penelitian untuk pengembangan kegiatan lebih lanjut bagi pihak yang memiliki kepentingan terhadap pengolahan kompos dan pupuk organik serta menjadi salah satu upaya pengolahan sampah secara mandiri.

\section{METODE}

\section{Pembuatan MOL}

Sayuran sisa sebanyak $5 \mathrm{~kg}$ dan 1 kg gula tebu dihaluskan, kemudian semua bahan yang telah dihaluskan dicampurkan ke dalam wadah toples yang berisi air cucian beras sebanyak 5 liter kemudian ditutup rapat. Selanjutnya air murni dimasukkan kedalam botol aqua yang telah dilubangi tutupnya, dan hubungkan selang dari botol aqua ke tutup toples yang telah diberi lubang. Diamkan selama 21 hari agar terjadi fermentasi, setelah 21 hari ampas di dalam wadah toples disaring dipisahkan antara ampas dan airnya. Air MOL sudah dapat digunakan ( modifikasi NOSC, 2008).

\section{Pengambilan sampel MOL}

Pengambilan sampel dari MOL sebanyak $5 \mathrm{ml}$ dilakukan pada saat pembuatan MOL pada 1 × 24 jam (T0), minggu pertama pada 7 × 24 jam (T1), minggu ke-2 pada $21 \times 24$ jam (T2), minggu ke-3 pada 21 x 24 jam (T3). Sampel MOL diambil menggunakan pipet tetes pada kedalam yang berbeda yaitu $4 \mathrm{~cm}, 14 \mathrm{~cm}$, dan $23 \mathrm{~cm}$ (Suhastyo et al. 2013).

\section{Isolasi Bakteri}

Sebanyak $1 \mathrm{ml}$ sampel dilarutkan ke dalam larutan $\mathrm{NaCl} 0,85 \%$, kemudian dihomogenkan dengan vortex. Suspensi diambil sebanyak $1 \mathrm{ml}$ lalu diencerkan mulai 10-1 sampai 10-6 dengan cara menghomogenkan $1 \mathrm{ml}$ sampel. Kemudian dari masing-masing pengenceran 10-4, 105, 10-6 ditumbuhkan pada medium NA dengan metode pour plate secara aseptis. Lalu diinkubasi pada suhu 37 oC selama 2x24 jam, kemudian diamati koloni bakteri dan dilakukan penghitungan jumlah bakteri dalam satuan $\mathrm{sel} / \mathrm{ml}$ (Widjajanti et al. 2006).

\section{Pemurnian}

Koloni yang tumbuh dengan ciri berbeda dimurnikan dengan cara distreak pada medium NA steril dalam cawan petri, lalu diinkubasi selama 2x24 jam pada suhu 37 oC. Teknik ini dilakukan 
secara berulang sampai diperoleh koloni yang diindikasikan murni. Koloni murni adalah koloni yang hanya terdiri dari satu jenis bakteri saja. Setelah mendapatkan koloni yang murni, selanjutnya isolat ditumbuhkan ke dalam medium NA miring sebagai stok kerja (Widjajanti et al. 2006).

\section{Karakterisasi}

Isolat bakteri dilakukan karakterisasi yang meliputi:

a. Morfologi koloni (Jutono 1983 dalam Widjajanti et al. 2006).

1. Isolat bakteri ditumbuhkan pada medium Nutrient Agar lempeng, lalu diamati bentuk pertumbuhan yang meliputi bentuk koloni standar, bentuk elevasi, tepi dan struktur dalam koloni bakteri.

2. Isolat bakteri ditumbuhkan pada Nutrient Agar tegak, lalu diamati bentuk pertumbuhan koloni standar.

3. Isolat bakteri ditumbuhkan pada medium Nutrient Agar miring, lalu diamati pertumbuhan koloni standar.

4. Isolat bakteri ditumbuhkan pada medium Nutrient Broth pada suhu 370C kemudian diamati pertumbuhan (aerob, fakultatif, anaerob dan mikroaerofil) dari masing-masing isolat.

\section{b. Morfologi Sel}

\section{Sifat Gram Bakteri}

Sediakanlah 4 buah kaca objek yang dibersihkan dengan alkohol 70\%. Siapkanlah olesan bakteri pada keempat buah kaca objek dengan jarak antara kedua olesan tersebut paling sedikit $2 \mathrm{~cm}$. Isolat bakteri berumur 24 jam diambil satu ose secara aseptis, diinokulasi ke dalam $9 \mathrm{ml}$ akuades steril, dihomogenkan dengan vortex. Kemudian satu tetes suspensi bakteri diambil dengan menggunakan pipet tetes steril, diratakan diatas kaca objek, kemudian dikering anginkan dan difiksasi di atas nyala api. Setelah dingin ditetesi dengan zat warna kristal violet kurang lebih 2-3 tetes selama 1 menit, lalu dibilas dengan aquades dan buanglah kelebihan zat warna. Kemudian ditetesi dengan larutan iodium selama 2 menit, lalu dicuci dengan air yang mengalir dan dikeringkan. Setelah itu lakukanlah pemucatan dengan alkohol 95\% selama 30 detik, dicuci dengan air mengalir dan dikeringkan. Setelah itu ditetesi dengan zat warna safranin selama 30 detik lalu dibilas dengan air, seraplah sisa air dengan kertas serap dan dikeringkan. Amati preparat dibawah mikroskop yaitu bentuk sel yang tampak. Warna ungu atau biru untuk gram positif dan untuk gram negatif. Diamati pula bentuk dari sel bakteri tersebut apakah bulat (coccus), batang (basil), atau bergelombang (spiral) (Hadioetomo 1993; Irianto 2006).

\section{Penyajian Data}

Data yang diperoleh dari pengamatan disajikan dalam bentuk foto dan tabel.

\section{HASIL DAN PEMBAHASAN}

Sampel MOL limbah sayuran terdiri atas 3 macam yaitu MOL ke-I (limbah sayuran, gula pasir, air cucian beras), II (limbah sayuran, gula merah, air cucian beras), dan III (limbah sayuran, gula pasir, air kelapa). Hasil isolasi dan pemurnian bakteri diperoleh berjumlah 79 jenis isolat bakteri yang terdiri atas 23 jenis isolat bakteri dari sampel MOL ke-1, 30 jenis isolat bakteri dari sampel MOL ke-II, dan 24 jenis isolat bakteri dari sampel ke-III data ditampilkan pada (Tabel 1). 
Tabel 4.1 Hasil isolasi dan pemurnian bakteri asal MOL limbah sayuran

\begin{tabular}{|c|c|c|c|c|}
\hline Asal Sampel & Waktu & $\begin{array}{l}\text { Jumlah sel } \\
\text { bakteri } \\
\text { (sel/mi) }\end{array}$ & $\begin{array}{l}\text { Jumlah } \\
\text { jenis }\end{array}$ & Kode isolat \\
\hline \multirow{4}{*}{ MOL I } & T0 & $8,00 \times 10^{7}$ & 6 & $\begin{array}{l}\text { 1(S1)T0, 2(S1)T0, } \\
\text { 3(S1) T0, 4(S1)To, }\end{array}$ \\
\hline & T1 & $4,30 \times 10^{8}$ & 6 & $\begin{array}{l}\text { 5(S1)T0, 12(S1)T0 } \\
\text { 1(S1)T1, 2(S1)T1, } \\
\text { 3(S1)T1, 4(S1)T1, } \\
\text { 5(S1)T1, 6(S1)T1 }\end{array}$ \\
\hline & $\mathrm{T} 2$ & $1,31 \times 10^{8}$ & 7 & $\begin{array}{l}1(\mathrm{~S} 1) \mathrm{T} 2,2(\mathrm{~S} 1) \mathrm{T} 2 \\
3(\mathrm{~S}) \mathrm{T} 2,4(\mathrm{~S} 1) \mathrm{T} 2 \\
5(\mathrm{~S} 1) \mathrm{T} 2,6(\mathrm{~S} 1) \mathrm{T} 2\end{array}$ \\
\hline & T3 & $1,01 \times 10^{8}$ & 5 & $\begin{array}{l}1(\mathrm{~S} 1) \mathrm{T} 3,2(\mathrm{~S} 1) \mathrm{T} 3 \\
3(\mathrm{~S} 1) \mathrm{T} 3,4(\mathrm{~S} 1) \mathrm{T} 3 \\
6(\mathrm{~S} 1) \mathrm{T} 3\end{array}$ \\
\hline \multirow[t]{4}{*}{ MOL II } & TO & $4,39 \times 10^{7}$ & 7 & $\begin{array}{l}\text { 3(S2)T0, 4(S2)T0, } \\
5(\mathrm{~S} 2) \mathrm{T0}, 6(\mathrm{~S} 2) \mathrm{T} 0 \\
8(\mathrm{~S} 2) \mathrm{T} 0,9(\mathrm{~S} 2) \mathrm{T} 0, \\
11(\mathrm{~S} 2) \mathrm{T} 0\end{array}$ \\
\hline & T1 & $6,20 \times 10^{8}$ & 8 & $\begin{array}{l}\text { 1(S2)T1, 2(S2)T1, } \\
\text { 3(S2) T1, 4(S2)T1, } \\
\text { 5(S2) T1, 6(S2)T1, } \\
7(\mathrm{~S} 2) \mathrm{T} 1,8(\mathrm{~S} 2) \mathrm{T} 1\end{array}$ \\
\hline & $\mathrm{T} 2$ & $5,30 \times 10^{8}$ & 8 & $\begin{array}{l}1(\mathrm{~S} 2) \mathrm{T} 2,2(\mathrm{~S} 2) \mathrm{T} 2, \\
3(\mathrm{~S} 2) \mathrm{T} 2,4(\mathrm{~S} 2) \mathrm{T} 2 \\
5(\mathrm{~S} 2) \mathrm{T} 2,6(\mathrm{~S} 2) \mathrm{T} 2 \\
7(\mathrm{~S} 2) \mathrm{T} 2,8(\mathrm{~S} 2) \mathrm{T} 2\end{array}$ \\
\hline & T3 & $4,95 \times 10^{8}$ & 7 & $\begin{array}{l}1(\mathrm{~S} 2) \mathrm{T} 3,2(\mathrm{~S} 2) \mathrm{T} 3, \\
3(\mathrm{~S} 2) \mathrm{T} 3,4(\mathrm{~S} 2) \mathrm{T} 3, \\
5(\mathrm{~S} 2) \mathrm{T} 3,6(\mathrm{~S} 2) \mathrm{T} 3, \\
7(\mathrm{~S} 2) \mathrm{T} 3\end{array}$ \\
\hline \multirow{4}{*}{ MOL III } & T0 & $9,10 \times 10^{6}$ & 5 & $\begin{array}{l}1(\mathrm{~S} 3) \mathrm{T} 0,2(\mathrm{~S} 3) \mathrm{T} 0 \\
3(\mathrm{~S} 3) \mathrm{T} 0,4(\mathrm{~S} 3) \mathrm{T} 0 \\
5(\mathrm{~S} 3) \mathrm{T} 0\end{array}$ \\
\hline & T1 & $2,25 \times 10^{7}$ & 7 & $\begin{array}{l}\text { 1(S3)T1, 2(S3)T1, } \\
\text { 3(S3) T1, 4(S3)T1, } \\
\text { 5(S3) T1, 6(S3)T1, } \\
7(\mathrm{~S} 3) \mathrm{T} 1\end{array}$ \\
\hline & $\mathrm{T} 2$ & $2,54 \times 10^{7}$ & 6 & $\begin{array}{l}1(\mathrm{~S} 3) \mathrm{T} 2,2(\mathrm{~S} 3) \mathrm{T} 2, \\
3(\mathrm{~S} 3) \mathrm{T} 2,4(\mathrm{~S} 3) \mathrm{T} 2\end{array}$ \\
\hline & T3 & $4,80 \times 107$ & 7 & $\begin{array}{l}1(\mathrm{~S} 3) \mathrm{T} 3,2(\mathrm{~S} 3) \mathrm{T} 3, \\
3(\mathrm{~S} 3) \mathrm{T} 3,4(\mathrm{~S} 3) \mathrm{T} 3, \\
5(\mathrm{~S} 3) \mathrm{T} 3,6(\mathrm{~S} 3) \mathrm{T} 3\end{array}$ \\
\hline $\begin{array}{l}\text { Total Jenis } \\
\text { Balteri }\end{array}$ & & & 79 & \\
\hline
\end{tabular}

Keterangan: T0: waktu ke-0, T1: waktu minggu ke1, T2: waktu minggu ke-2, T3: waktu minggu ke-3

MOL dibuat sebagai media hidup dan mengandung mikroorganisme yang dapat bersifat dekomposisi bahan organik dan memiliki potensi sebagai pemacu pertumbuhan tanaman. Berdasarkan hasil isolasi dapat dilihat pada Tabel.1 bahwa diperoleh data secara keseluruhan dari sampel MOL ke-I, II, dan III jumlah sel bakteri tertinggi terdapat pada sampel MOL ke-II dengan jumlah jenis bakteri paling banyak. Faktor yang mempengaruhi jumlah populasi mikroba untuk tumbuh pada media fermentasi antara lain $\mathrm{pH}$, oksigen, dan substrat. Sumber nutrisi utama yang diperoleh mikroba dari cairan MOL yaitu glukosa. Glukosa pada sampel MOL ke-II diduga paling tinggi kandunganny karena bersumber dari gula merah dan ditambah dengan air cucian beras yang juga menjadi sumber kandungan karbohidrat dalam sampel MOL ke-II. Didukung Suhastyo
(2011) menyatakan bahwa karbohidrat merupakan substrat utama yang diperlukan dalam proses fermentasi, sumber karbohidrat dari cairan MOL dapat berasal dari air gula dan air cucian beras sehingga akan meningkatkan kandungan C-organik dalam cairan MOL. Menurut Juanda, et al (2011), fermentasi merupakan proses oksidasi anaerob karbohidrat menghasilkan alkohol dan asam-asam. Gula jika difermentasi akan menghasilkan etanol, asam laktat, asam butirat, aseton, dan hidrogen.

Sampel MOL ke-I memiliki jumlah sel bakteri yang tidak berbeda nyata terhadap sampel MOL ke-II, tetapi berbeda nyata dari sampel MOL ke-3. Sampel MOL ke-2 memiliki 23 jenis bakteri yang tidak jauh berbeda dari sampel MOL ke-3 yaitu sebanyak 24 jenis bakteri, namun sampel MOL ke I dan II memiliki jumlah jenis bakteri yang berbeda jauh dari sampel MOL ke-1 dengan jumlah 30 jenis bakteri (Tabel 1). Perhitungan jumlah sel bakteri mengalami peningkatan pada waktu minggu ke-1 di sampel MOL I, II, dan III (Gambar 1). Hal ini dikarenakan hasil penguraian bahan organik yang dilakukan bakteri dalam memperoleh nutrisi sehingga laju pertumbuhan mengalami peningkatan. Peningkatan bakteri juga bersamaaan dengan jumlah jenis bakteri yang semakin meningkat. Pada minggu ke-2 dan minggu ke-3 di sampel MOL ke-I dan II mengalami penurunan. Hal ini diduga kondisi substrat yang berkurang dalam mendukung pertumbuhan bakteri, sehingga memasuki waktu fermentasi minggu ke-3 jumlah sel bakteri dan diikuti jenis bakteri yang berkurang. Suhastyo (2011) menyatakan kondisi total populasi mikrob pada MOL keong dan MOL urin kelinci rata-rata optimum pertumbuhan pada hari ke-7 sedangkan MOL bonggol pisang pada hari ke-14. Menurut Budiyani dkk (2016) bahwa hasil kandungan C-organik pada fermentasi dua minggu masih mengalami peningkatan dan penurunan terjadi pada minggu ke enam. Perbedaan ini dikarenakan komposisi yang tidak sama pada masing-masing perlakuan. Sampel 
MOL ke-3 pada grafik perhitungan jumlah sel bakteri menunjukkan pertumbuhan yang berbeda dengan sampel MOL ke-I dan II. Pertumbuhan jumlah sel bakteri mengalami peningkatan sampai waktu minggu ke-3. Hal ini diduga karena pertumbuhan mikrob yang ada dalam cairan MOL ke-III masih beradaptasi dengan lingkungan sekitar pada minggu ke-1 dan memulai memanfaatkan substrat memasuki minggu ke-2 dan 3. Peningkatan populasi bakteri disebabkan kandungan C-organik telah dirombak mikroorganisme menjadi senyawa yang lebih sederhana dalam larutan MOL. Semakin lama proses fermentasi maka akan semakin menurun jumlah populasi bakteri yang diikuti dengan berkurangnya substrat bagi pertumbuhan (Budiyani dkk, 2016). Menurut Budiyanto, (2002) air kelapa merupakan media yang baik untuk pertumbuhan mikroorganisme selama proses fermentasi karena air kelapa mengandung 7,27\% karbohidrat; 0,29\% protein; beberapa mineral antara lain 312 mg L-1 kalium; 30 mg L-1 magnesium; 0,1 mg L-1 besi; 37 mg L-1 fosfor; 24 mg L-1 belerang; dan 183 mg L-1 klor.

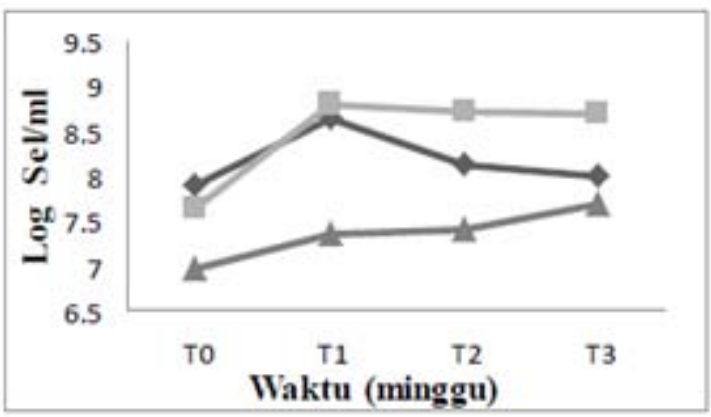

Gambar 1. Perhitungan Jumlah sel bakteri yang diisolasi dari MOL limbah sayuran

(a) sampel MOL ke-1 -- --

(b) sampel MOL ke-2 -----

(c) sampel MOL ke-3 --

Isolat bakteri hasil isolasi dan pemurnian yang dilanjutkan uji karakterisasi koloni, morfologi sel hanya berjumlah 28 isolat bakteri. Uji karakterisasi isolat dilakukan sebagai uji awal untuk mengidentifikasi bentuk-bentuk koloni bakteri. Sebanyak 28 isolat bakteri.
Uji karakterisasi sampel bakteri asal MOL pada waktu awal fermentasi yang diperoleh terdapat 28 bakteri. Pada MOL ke- I (waktu T0) terdapat 6 isolat dengan masing-masing kode 1 (S1)T0, 2 (S1) T0, 3 (S1)T0, 4 (S1) T0, 5 (S1)T0 dan 12(S1)T0, MOL II (waktu T0) terdapat 7 isolat dengan masing-masing kode $3(\mathrm{~S} 2)$ T0, 4(S2)T0, 5(S2)T0, 6(S2)T0, 8(S2)T0, 9(S2)T0, 11(S2)T0. Pada MOL II (T1) terdapat 8 jumlah isolat dengan masingmasing kode 1(S2)T1, 2(S2)T1, 3(S2) T1, 4(S2)T1, 5(S2)T1, 6(S2)T1, 7(S2)T1, 8(S2)T. Pada MOL III waktu T1 terdapat 7 isolat dengan masing-masing kode $1(\mathrm{~S} 3)$ T1, 2(S3)T1, 3(S3)T1, 4(S3)T1, 5(S3)T1, 6(S3)T1 dan 7(S3)T1 dan MOL 1 (T2) terdapat 1 isolat dengan kede 1(S1)T2. Dari masing-masing sampel terlihat bahwa ratarata memiliki bentuk yang bulat dengan tepian tidak rata dan berwarna putih. Pada bakteri asal limbah sayuran terlihat pada tabel 2. Terlihat bahwa pada MOL 1(Waktu T0) pada media agar tegak 3 isolat pertama Villous dan pada 3 isolat terkahir masingmasing Rhizoid, dan untuk media Agar Miring bervariasi anatara Spreading, Arborescent, Ecninulate dan Filifrom. Untuk MOL II(T0), MOL II (T1) dan MOL III(T0) sama halnya dengan MOL I (T0) karakter masing-masing isolat bervariasi. Namun pada Pertumbuhan pada media cair NB dapat dilihat paling banyyak Anaerob Fakultatif. Sesuai dengan ang dijelaskan oleh Surono (2004) menjelaskan bahwa variasi karakteristik bakteri normal terjadi. Dijelaskan juga oleh Volk dan Wheeler (1988) dalam Isdaryanti (2011) perbedaan bentuk pertumbuhan dari tiap isolat bakteri pada medium agar cawan, mengindikasikan bahwa semua isolat tersebut berasal dari jenis bakteri yang berbeda, dimana bentuk koloni dapat dijadikan dasar dalam identifikasi bakteri.

\section{SIMPULAN}

Hasil penelitian diperoleh isolat bakteri yang berasal dari MOL limbah sayuran yang terdiri atas 3 macam perlakuan yaitu MOL ke-I (limbah sayuran, gula pasir, air cucian beras), II (limbah 
sayuran, gula merah, air cucian beras), dan III (limbah sayuran, gula pasir, air kelapa). Hasil isolasi dan pemurnian bakteri diperoleh berjumlah 79 jenis isolat bakteri yang terdiri atas 23 jenis isolat bakteri dari sampel MOL ke-1, 30 jenis isolat bakteri dari sampel MOL ke-II, dan 24 jenis isolat bakteri dari sampel ke-III. Bahwa diperoleh data secara keseluruhan dari sampel MOL ke-I, II, dan III jumlah sel bakteri tertinggi terdapat pada sampel MOL ke-II dengan jumlah jenis bakteri paling banyak.

\section{DAFTAR PUSTAKA}

Batara, L.N. (2015). Kualitas mikroorganisme lokal (MOL) yang digunakan pada penanaman padi (Oryza sativa L.) dengan metode system of rice intensification (SRI) organik. Tesis. Pasacasarjana IPB.

Budiyani, N.K., Soniari, N.N dan Sutari, N.W.S. (2016). Analisis Kualitas Mikroorganisme Lokal (MOL.) Bonggol Pisang. E-Jurnal Agroteknologi Tropika. Vol 5 (1): Universitas Udayana. Bali.

Budiyanto, M. (2002). Mikrobiologi Terapan. Universitas Muhammadiya. Malang.

Hadiotomo, R. S. (1995). Mikrobiologi Dasar Dalam Praktek Teknik dan Prosedur Dasar Laboratorium. Gramedia.

Husen E, Irawan. (2008). Efektivitas dan efisiensi mikroba dekomposer komersialdan lokaldalampembuatan kompos jerami. http:www.balittanah. litbang.deptan.go.id/ dokumen/ prosiding2008pdf/ edihusen.pdf.

Irianto, K. (2006). Mikrobiologi, Menguak Dunia Mikroorganisme. Jilid 1. Yrama Widya. Bandung.

Isdaryanti, Abdullah. A dan Nawir, N.H.A. (2011). Isolasi dan karakerisasi bakteri pendegradasi Lignoselulosa Asal Rumen Sapi. Jurusan FMIPA UNHAS. Jurnal tidak diterbitkan.
Juanda, Irfan, dan Nurdiana. (2011). Pengaruh Metode dan Lama Fermentasi terhadap Mutu MOL (Mikroorganisme Lokal). Jurnal Floratek 6: 140-143. Fakultas Pertanian Unsyiah, Darussalam Banda Aceh.

Kesumaningwati R. (2015). Penggunaaan MOL bonggol pisang (Musa paradisiaca) sebagai dekomposer untuk pengomposan tandan kosong kelapa sawit. J Ziraa'ah vol 40 (1): 40-45 hlm.

Surono, I.S. (2004). Prebiotik susu fermentasi dan kesehatan. Tri Cipta Kara. Jakarta

Sutari, N. W. S. (2010). Uji Berbagai Jenis Pupuk Cair Biourine terhadap Pertumbuhan Dan Hasil Tanaman Sawi Hijau (Brassica juncea L.). Agritrop : Jurnal Ilmu-Ilmu Pertanian (Journal On Agricultural Sciences) edisi desember 2010. Vol.29.

Suyanto A, Irianti ATP. (2015). Efektivitas Trichoderma sp dan mikroorganisme local (MOL) sebagai decomposer dalam meningkatkan kualitas pupuk organik alami dari beberapa limbah tanaman pertanian. Jurnal Agrosains Vol 12 (2). ISSN 1693-5225. Hal 1-7.

Suhastyo AA. (2011). Studi mikrobiologi dan sifat kimia mikroorganisme lokal (MOL) yang digunakan pada budidaya padi metode SRI (system of rice intensif ication). Tesis. Bogor (ID): Intitut Pertanian Bogor.

Suhastyo AA, Anas I, Santosa DA, Lestari Y. (2013). Studi mikrobiologi sifat kimia mikroorganisme lokal (MOL) yang digunakan pada budidaya padi metode SRI (System of Rice Intensification). J Sainteks Vol x (2): 29-39 hlm.

Purwasasmita M, Kunia K. (2009). Mikroorganisme lokal sebagai pemicu siklus kehidupan dalam bioreaktor tanaman. Seminar Nasional Teknik Kimia Indonesia- 
SNTKI 2009. Bandung 19-20

Oktober 2009.

Widjajanti, H., Munawar \& Nafiah. (2006).

Isolasi, Seleksi, dan Karakterisasi

Bakteri Hidrokarbonoklastik dari

Limbah Cair Kegiatan Eksplorasi

Minyak Bumi. Jurnal Pengelolahan

Lingkungan \& Sumber Daya Alam.

Vol6(4): 22-31 hlm 